\title{
Rooting Depth, Growth and Yield of Corn as Affected by Soil Water Availability in an Ultisol and an Oxisol ${ }^{1,2}$
}

\author{
A. Wahab, H. Talleyrand, and M. A. Lugo-López ${ }^{3}$
}

\begin{abstract}
Relationships between rooting depth, growth, and yields of corn and soil water availability in an Ultisol and an Oxisol are presented. Soil and crop management techniques considered to be adequate for maximum yield were used at the two experimental sites. At each site one treatment was irrigated as often as necessary to maintain a water tension of less than 1 bar. Soil properties, plant growth, effective rooting depth, soil water availability, plant water deficits, crop yields, and weather conditions were recorded. During a prolonged drought and at grain filling, corn growing in a typical Oxisol extracted soil water to a depth of $120 \mathrm{~cm}$, and plants became water stressed after a soil water tension of 15 bars developed at $90 \mathrm{~cm}$. In a typical Ultisol plants could not extract water effectively below $30 \mathrm{~cm}$. Plants grew better in the Oxisol than in the Ultisol. Grain yields approached 9.4 tons/ha in the former but only 3.1 tons/ha in the latter.
\end{abstract}

\section{INTRODUCTION}

On nonirrigated farms where good cultivation practices are followed, inadequate rainfall is one of the main factors limiting crop yield (1). This situation occurs even during the rainy seasons in the humid tropics (4). Other physical and chemical factors such as soil compaction, low oxygen diffusion rates, temperature, humidity, and high levels of certain metals can limit the extent of proliferation of the root system $(3,6,8)$. With smaller root systems and during a drought, the possibility of the roots' extracting all of the readily available moisture before the normal photosynthetic activity of the day is completed is decreased. Plants are capable of partially recovering during the low transpiration periods at

${ }^{1}$ Manuscript submitted to Editorial Board May 22, 1975.

${ }^{2}$ Joint contribution from the Agricultural Experiment Station, University of Puerto Rico, Mayagüez Campus, Río Piedras, P.R., and the Department of Agronomy, Cornell University, Ithaca, N.Y. This study was part of the investigations supported by USAID under research contract ta-c-1104 entitled: "Soil Fertility in the Humid Tropics."

${ }^{3}$ Assistant Soil Scientist, University of Puerto Rico, Agricultural Experiment Station, Research Assistant, Cornell University, and Professor and Soil Scientist, University of Puerto Rico Agricultural Experiment Station, respectively. The senior author is now Crop Development Officer at Booker Central Services, Ltd. Georgetown, Guyana. 
night only to face the possibility of not meeting transpirational demands on the following day by an even greater margin. When such periods are long enough or frequent enough, crop growth and yield are diminished (3).

To obtain higher plant yields and more efficient use of water, quantitative knowledge of the relationship of water content and its availability, and of plant rooting depth in soils is required. This paper presents data relating plant growth, crop yield, and rooting depth of corn in a typical Oxisol and a typical Ultisol to soil water availability under field conditions. The information presented can be valuable to the farmer in choosing a crop and/or crop variety to exploit available soil moisture. It will also be useful in soil management systems to schedule irrigation to coincide with periods of moisture stress.

\section{MATERIALS AND METHODS}

FIELD STUDIES

Seed of hybrid Pioneer X-306, a well-adapted corn for the Tropics, with $85 \%$ germination was used. Three test plots measuring $10 \times 5 \mathrm{~m}$ were selected at Barranquitas at an elevation of $669 \mathrm{~m}$ and at Corozal at an elevation of $212 \mathrm{~m}$. One plot per crop site was irrigated throughout the experiment to maintain a soil moisture tension of 0.2 bar or less. At Barranquitas the soil has been classified as Catalina, an Oxisol (Tropeptic Haplortox, clayey, kaolinitic, isohyperthermic). At Corozal the soil is Humatas, an Ultisol (Typic Tropohumults, clayey, mixed, isohyperthermic).

The plow layer of each plot was sampled for soil $\mathrm{pH}$ determinations. Following this, the land was plowed and then the plots were differentially limed with $\mathrm{Ca}(\mathrm{OH})_{2}$ to a $\mathrm{pH}$ of about 6.0 after which they were disced. One month later and just prior to planting, each plot received a blanket application of fertilizers as follows: $30 \mathrm{~kg} / \mathrm{ha}$ of $\mathrm{N}$ as urea; $200 \mathrm{~kg} / \mathrm{ha}$ of $\mathrm{P}$ as superphosphate; $100 \mathrm{~kg} / \mathrm{ha}$ of $\mathrm{K}$ as sulfate; $100 \mathrm{~kg} / \mathrm{ha}$ of $\mathrm{Mg}$ as sulfate; $5 \mathrm{~kg} / \mathrm{ha}$ of $\mathrm{Zn}$ as sulfate; and $2 \mathrm{~kg} / \mathrm{ha}$ of $\mathrm{B}$ as Borax.

Thirty days after planting an additional $90 \mathrm{~kg} / \mathrm{ha}$ of $\mathrm{N}$ was banded 6 $\mathrm{cm}$ from the rows. Dasanit ${ }^{4}$ was applied prior to planting at the rate of 1 $\mathrm{kg} / \mathrm{plot}$ for nematode control.

Both sites were planted on January 12,1973 , in 76 - $\mathrm{cm}$ rows. A seeding rate was used to obtain equal stands of 3.3 corn plants $/ \mathrm{m}$ of row. At Corozal the plots were replanted on February 9.

${ }^{4}$ Trade names are used in this publication solely for the purpose of providing specific information. Mention of a trade name does not constitute a guarantee or warranty of equipment or materials by the Agricultural Experiment Station of the University of Puerto Rico or an endorsement over other equipment or materials not mentioned. 
Immediately after planting, test areas were sprayed and treated with preemergence herbicide (Simazine) and rat poison (Warfarin). Both sites were irrigated as often as necessary to ensure adequate moisture for germination and early plant growth. Weekly applications of fungicide (Dithane) and insecticide (Sevin) were made at both sites following germination to protect against leaf-eating insects and damping-off organisms. Weeds were eliminated by hand as often as necessary.

After planting, duplicate sets of calibrated gypsum soil moisture blocks were installed $15 \mathrm{~cm}$ from the center row of each plot at depths of $15,30,45,60,90$, and $120 \mathrm{~cm}$. As soon as the blocks had attained equilibrium with the soil, readings of soil moisture were recorded bi-weekly; and as soil moisture diminished with crop growth, readings were taken more frequently.

To compare plant growth during drought versus growth under adequate moisture conditions, one corn plot at each site was irrigated as often as necessary to maintain a tension of 0.2 bar or less until crop growth ceased. Determinations of soil strength were made with a recording soil penetrometer having a $30^{\circ}$ tapered cone with an area of $1.29 \mathrm{~cm}^{2}(5)$. Measurements were made at depths of 0 to 15,15 to 30 , and 30 to $45 \mathrm{~cm}$, respectively. All determinations were made when the 0 to 45 $\mathrm{cm}$ of soil layer was at field capacity. Penetrometer resistance measurements were taken at 12 sites from each field plot, and the values were averaged and reported as resistance in bars.

Commencing 43 days after planting, and at weekly intervals thereafter until corn plants had tasseled ( 80 to 84 days), plant heights were determined on 30 test plants per plot. Height was measured from the base of the plant to the tip of the youngest fully unrolled leaf. Plant diameters were determined by taking the average value of two measurements at the fifth node from the proximal end at 100 days after seeds were planted. As corn approached physiological maturity, trenches were dug between rows to visually observe maximum depth and pattern of rooting.

Corn was harvested at both sites on June 18, and grain and stover yields were computed. On this date 157 and 129 days had elapsed from the dates of planting at Barranquitas and Corozal, respectively. Grain yields were expressed as kilograms per hectare at $15 \% \mathrm{H}_{2} \mathrm{O}$. Stover yields were also expressed as kilogramis per hectare but on a 1.00\% dry matter basis.

A record of air temperature, relative humidity, rainfall, and evaporation from a class A pan was kept during the studies.

\section{LABORATORY STUDIES}

As the soil moisture of the nonirrigated plots diminished and plants began to wilt, portions of leaves were sampled for leaf water deficit 
(LWD) determinations using the method of Catsky (2). Plants were 78 and 56 days old at Barranquitas and Corozal, respectively, when the measurements were started. Leaves were sampled from six test plants per plot. Leaf segments about $6 \mathrm{~cm}$ in length were dissected from near the middle of the eighth uppermost leaf. Samples were chilled in a cooler and transferred to a refrigerator upon arrival at the laboratory. The following morning leaf samples were weighed, then placed for 4 hr in a water-saturated environment. The samples were kept under a light intensity of $65 \mathrm{fc}$ at $23^{\circ} \mathrm{C}$. The turgid weight was then obtained, and after drying for $24 \mathrm{hr}$ at $65^{\circ} \mathrm{C}$, the dry weight was determined. The leaf water deficit was calculated as follows:

$$
\mathrm{LWD}=\frac{\text { Turgid weight }- \text { Initial weight }}{\text { Turgid weight }- \text { Oven dry weight }} \times 100
$$

Bulk densities were determined from undisturbed soil cores taken at depths of 15 to $22.5,30$ to $37.5,50$ to 75 , and 75 to $82.5 \mathrm{~cm}$, using standard techniques. As the soil water diminished, the moisture content of the soil profile was determined gravimetrically. Determinations of field capacity of the plow layer were made on both soils. Composite samples taken from the test plots 60 days after planting at depths of 0 to 20, and 20 to 40 $\mathrm{cm}$ were air-dried and analyzed for $\mathrm{pH}, \mathrm{CEC}$, and exchangeable $\mathrm{Al}, \mathrm{Ca}$, $\mathrm{Mg}, \mathrm{K}, \mathrm{P}$, and $\mathrm{Mn}$.

\section{RESULTS AND DISCUSSION}

\section{SOIL PROPERTIES}

Some physical and chemical properties of the test soils at Barranquitas and Corozal are presented in table 1. The soil at Barranquitas had a greater capacity to hold water than that at Corozal. Conversely, bulk densities were greater at Corozal than at Barranquitas at all the depths measured. These differences may be attributed to the greater degree of compaction and smaller pore space of the soil at Corozal versus that at Barranquitas. In Corozal penetrometer resistances were much higher at all soil depths than at Barranquitas (table 1). The high soil compaction at the Corozal site could impede root penetration severely and could reduce both the total air capacity and air transmission rate of the soil (8). The total root surface area was smaller and absorbing capacity was lower in plants growing in Corozal than in Barranquitas.

The cation exchange capacity (CEC) at Corozal is markedly higher than that at Barranquitas. Also the CEC (meq/100g) of the $0-$ to $20-\mathrm{cm}$ soil layer at Barranquitas is almost twice that at 20 to $40 \mathrm{~cm}$. The increase is not as striking at Corozal. No Mn was detected at Corozal, whereas it was detected at both the 0- to 20- and 20- to 40- $\mathrm{cm}$ depths at Barranquitas. Al was much higher at Corozal than at Barranquitas, partic- 
TABLE 1.-Some physical and chemical properties of soils at Barranquitas (Oxisol-Catalina clay) and Corozal (Ultisol-Humatas clay) experimental sites

\begin{tabular}{|c|c|c|c|}
\hline \multicolumn{2}{|c|}{ Property } & Oxisol & Ultisol \\
\hline \multicolumn{2}{|c|}{$\begin{array}{l}\text { Field capacity of plow layer, } \% \\
\text { Bulk density }(\mathrm{g} / \mathrm{cc})\end{array}$} & 47.25 & 41.30 \\
\hline & 15 to $23 \mathrm{~cm}$ & 1.03 & 1.12 \\
\hline & 30 to $38 \mathrm{~cm}$ & 1.13 & 1.22 \\
\hline & 50 to $58 \mathrm{~cm}$ & 1.12 & 1.24 \\
\hline & 75 to $84 \mathrm{~cm}$ & 1.10 & 1.33 \\
\hline \multicolumn{4}{|c|}{ Penetrometer resistance (bars) } \\
\hline & 0 to $15 \mathrm{~cm}$ & 17.4 & 28.0 \\
\hline & 15 to $30 \mathrm{~cm}$ & 21.5 & 26.0 \\
\hline & 30 to $45 \mathrm{~cm}$ & 18.6 & 25.0 \\
\hline \multicolumn{4}{|c|}{ Cation exchange capacity (meq/100 g) } \\
\hline & 0 to $20 \mathrm{~cm}$ & 9.00 & 15.24 \\
\hline & 20 to $40 \mathrm{~cm}$ & 5.41 & 13.48 \\
\hline \multicolumn{4}{|l|}{$\mathrm{pH}$} \\
\hline & 0 to $20 \mathrm{~cm}$ & 5.01 & 4.99 \\
\hline & 20 to $40 \mathrm{~cm}$ & 5.07 & 4.51 \\
\hline \multicolumn{4}{|c|}{$\begin{array}{l}P(p / m) \\
\text { (Bray No. 2) }\end{array}$} \\
\hline & 0 to $20 \mathrm{~cm}$ & 23.40 & 40.30 \\
\hline & 20 to $40 \mathrm{~cm}$ & 3.56 & 4.96 \\
\hline \multicolumn{4}{|c|}{ Exchangeable cations (meq/100 g) } \\
\hline \multirow[t]{2}{*}{$\mathrm{Al}$} & 0 to $20 \mathrm{~cm}$ & .64 & 1.48 \\
\hline & 20 to $40 \mathrm{~cm}$ & .48 & 9.24 \\
\hline \multirow[t]{2}{*}{$\mathrm{Ca}$} & 0 to $20 \mathrm{~cm}$ & 3.32 & 7.44 \\
\hline & 20 to $40 \mathrm{~cm}$ & 2.61 & 2.13 \\
\hline \multirow[t]{2}{*}{$\mathrm{Mg}$} & 0 to $20 \mathrm{~cm}$ & 1.08 & 1.74 \\
\hline & 20 to $40 \mathrm{~cm}$ & .53 & .49 \\
\hline \multirow[t]{2}{*}{ K } & 0 to $20 \mathrm{~cm}$ & .77 & .76 \\
\hline & 20 to $40 \mathrm{~cm}$ & .22 & .45 \\
\hline \multirow[t]{2}{*}{$\operatorname{Mn}(\mathrm{p} / \mathrm{m})$} & 0 to $20 \mathrm{~cm}$ & 38.40 & .00 \\
\hline & 20 to $40 \mathrm{~cm}$ & 2.00 & .00 \\
\hline
\end{tabular}

ularly so in the 20- to $40-\mathrm{cm}$ layer. Soil $\mathrm{pH}$ of the plow layer was essentially the same (5.0) at both sites. However, soil pH of the 20- to 40-cm layer at Corozal was 0.6 lower than that at Barranquitas.

\section{PLANT GROWTH}

Differences in plant growth of corn growing with and without irrigation in an Oxisol and an Ultisol are presented in figure 1. Plants at Barranquitas were 40 and $49 \%$ taller than those at Corozal for the irrigated and nonirrigated plots, respectively. Also, plant diameters at the fifth node from the proximal end were 50 to $70 \%$ greater at Barranquitas than at 
Corozal for the irrigated and nonirrigated plots as shown in the following tabulation:

$\begin{array}{ccc}\text { Soil } & \text { Irrigated } & \text { Nonirrigated } \\ \text { Oxisol } & 2.69 \mathrm{~cm} & 2.69 \mathrm{~cm} \\ \text { Ultisol } & 1.74 \mathrm{~cm} & 1.58 \mathrm{~cm}\end{array}$

During the period that plant measurements were taken, nonirrigated plots at Barranquitas and Corozal had received 342.9 and $741.9 \mathrm{~mm}$ of rainfall, respectively. However, it should be noted from table 2 that during the most active stages of vegetative growth both sites experienced from 20 to 30 consecutive days of negligible or no rainfall. Ensuing data will show that during this drought period, plants growing at Barranquitas extracted water from a depth greater than $90 \mathrm{~cm}$. Those at Corozal severely wilted when soil moisture at $45 \mathrm{~cm}$ was at field capacity.

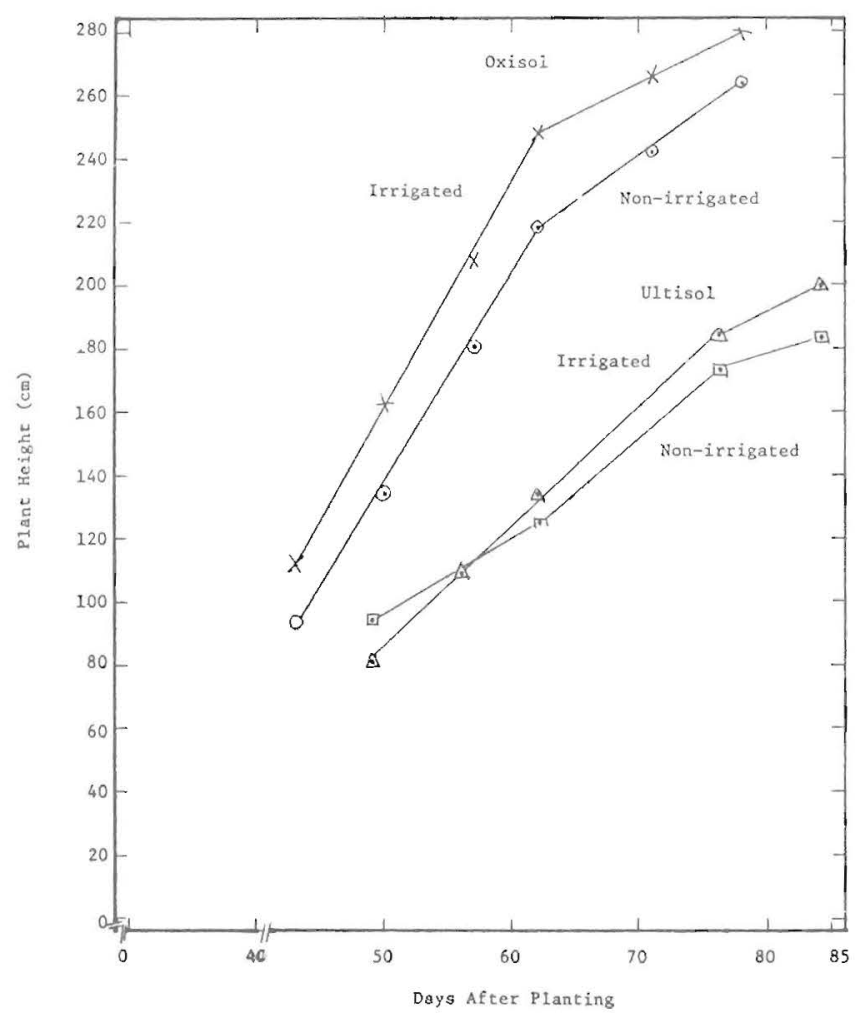

FIG. 1.-Differences in corn plant growth with and without irrigation in an Oxisol and an Ultisol. 
TABle 2.-Meteorological data for experimental sites from January 1 through May 31, 1973'

\begin{tabular}{|c|c|c|c|c|c|c|c|c|c|c|c|c|}
\hline \multirow{3}{*}{ Days } & \multicolumn{12}{|c|}{ Rainfall (mm) } \\
\hline & \multicolumn{6}{|c|}{ Barranquitas } & \multicolumn{6}{|c|}{ Corozal } \\
\hline & Jan. & Feb. & March & April & May & June & Jan. & Feb. & March & April & May & June \\
\hline 1 & 2 & 0.00 & 11.93 & 0.00 & 0.00 & 0.00 & 3.30 & 0.76 & 1.26 & 0.76 & 0.00 & 46.98 \\
\hline 2 & & 8.12 & .76 & .00 & 3.04 & .00 & .76 & 15.74 & .00 & .76 & 27.68 & .00 \\
\hline 3 & & .00 & .00 & 11.43 & 34.54 & .00 & 1.26 & .00 & .00 & .00 & .00 & .00 \\
\hline 4 & & 1.52 & .00 & .00 & .00 & .00 & .50 & .00 & .00 & .00 & .00 & .00 \\
\hline 5 & & .00 & .00 & .00 & .00 & .00 & 2.79 & .00 & .00 & .00 & .00 & 3.04 \\
\hline 6 & & .25 & 8.38 & .00 & .00 & 11.17 & .50 & .00 & 2.79 & .00 & .00 & 2.79 \\
\hline 7 & & 74.16 & .00 & .00 & 1.01 & .00 & .00 & 34.29 & 4.57 & .00 & .00 & .00 \\
\hline 8 & & 4.06 & .00 & .00 & .00 & .00 & .00 & 8.12 & .00 & .00 & .00 & .00 \\
\hline 9 & & .00 & 10.15 & .00 & .00 & .00 & 1.52 & .00 & 20.82 & .00 & .00 & .00 \\
\hline 10 & & .00 & .00 & .00 & .00 & .00 & .00 & .00 & .00 & .00 & .00 & 12.70 \\
\hline$\cdot 11$ & & .00 & .00 & .00 & .00 & .00 & .00 & .00 & .00 & .00 & .00 & 30.47 \\
\hline 12 & 53.33 & .00 & .00 & .00 & .00 & 7.87 & .00 & .00 & 17.77 & .00 & 1.26 & 1.52 \\
\hline 13 & & 34.03 & 19.30 & .00 & .00 & 6.85 & .00 & 24.63 & 1.01 & .00 & .00 & 3.80 \\
\hline 14 & & .00 & .50 & .00 & 6.60 & .00 & .00 & 92.70 & 13.20 & .00 & .50 & 11.68 \\
\hline 15 & & 24.89 & 1.01 & .00 & .00 & .00 & .00 & 3.30 & .00 & .00 & .00 & .00 \\
\hline 16 & & .00 & .00 & .00 & .00 & .00 & .00 & .00 & 1.52 & .00 & .25 & .00 \\
\hline 17 & & .00 & .00 & 1.01 & 4.06 & .00 & .00 & .00 & .00 & .00 & .00 & 4.31 \\
\hline 18 & & .00 & .00 & .25 & .00 & 11.93 & 1.01 & .00 & .00 & 1.26 & .00 & .50 \\
\hline 19 & & .00 & .00 & .00 & .00 & .00 & .00 & .00 & .00 & 6.35 & .00 & .00 \\
\hline 20 & & .00 & 2.03 & .00 & .00 & .00 & .00 & .00 & .00 & 31.75 & .00 & .00 \\
\hline 21 & & 12.70 & .00 & .00 & .00 & .00 & .00 & .00 & .00 & 199.38 & .00 & .00 \\
\hline 22 & 3.55 & 16.50 & .00 & .00 & 1.26 & 1.01 & .00 & 1.26 & .00 & 28.44 & .00 & .00 \\
\hline 23 & & .00 & .00 & .00 & .00 & .00 & 3.04 & 5.07 & .00 & 109.21 & .00 & .00 \\
\hline 24 & & .00 & .00 & 105.40 & .00 & .00 & .25 & .00 & .00 & 28.44 & .00 & .00 \\
\hline 25 & & .00 & .00 & .00 & .00 & .00 & .00 & .00 & .00 & .00 & .00 & .00 \\
\hline
\end{tabular}


TABLE 2.-continued

\begin{tabular}{|c|c|c|c|c|c|c|c|c|c|c|c|c|}
\hline 26 & & 7.36 & .00 & 1.01 & .00 & .00 & 28.44 & .00 & 9.65 & .00 & .00 & .00 \\
\hline 27 & & .00 & 30.22 & .00 & .00 & .00 & .50 & 1.52 & .00 & .00 & .00 & .00 \\
\hline 28 & & .00 & .00 & .00 & .00 & .00 & 9.90 & 4.31 & .00 & .00 & .00 & .00 \\
\hline 29 & 3.04 & .00 & 3.55 & .00 & .00 & .00 & .00 & .00 & .00 & .00 & .00 & .00 \\
\hline 30 & & .00 & .00 & .00 & .00 & .00 & .00 & .00 & .00 & .00 & .00 & .00 \\
\hline 31 & & .00 & .00 & .00 & .00 & .00 & .00 & .00 & .00 & .00 & .00 & .00 \\
\hline Total & 59.94 & 183.64 & 87.88 & 119.12 & 50.54 & 38.86 & 53.84 & 191.76 & 72.64 & 406.40 & 29.71 & 117.85 \\
\hline $\begin{array}{l}\text { Monthly evaporation } \\
\text { (mm) }\end{array}$ & - & 86.35 & 113.53 & 152.39 & 171.19 & 132.07 & 99.31 & 88.89 & 113.79 & 152.90 & 172.46 & 144.77 \\
\hline $\begin{array}{l}\text { Average maximum } \\
\text { temperature }\left({ }^{\circ} \mathrm{C}\right)\end{array}$ & - & 24.3 & 25.4 & 26.6 & 27.6 & a & 28.0 & 27.6 & 28.8 & 29.8 & 31.6 & 30.55 \\
\hline $\begin{array}{l}\text { Average minimum } \\
\text { temperature }\left({ }^{\circ} \mathrm{C}\right)\end{array}$ & - & 17.1 & 17.8 & 17.5 & 19.3 & a & 18.6 & 16.9 & 18.8 & 18.5 & 20.5 & 21.1 \\
\hline
\end{tabular}

${ }^{1}$ At both sites solar radiation ranges from an average of 300 langleys/day in the winter to 500 langleys/day in the summer.

${ }^{2}$ Cumulative rainfall for the three intervals indicated. 


\section{EFFECTIVE ROOTING DEPTH}

Figures 2 and 3 show the pattern of soil water extraction by corn plants growing in an Oxisol and an Ultisol. At the beginning of a drought period on March 1 (fig. 2), the entire Oxisol profile (15 to $120 \mathrm{~cm}$ ) was at field capacity. However, 33 days later, roots were extracting water from a depth of $90 \mathrm{~cm}$. During this period, 75 to $95 \mathrm{~mm}$ of rain were recorded, and evaporation from a class A pan accounted for $118.6 \mathrm{~mm}$. By April 13 roots were effectively extracting moisture from a depth of $120 \mathrm{~cm}$. On this date the soil moisture tension was 15 bars at depths of $15,30,45$, and 60 $\mathrm{cm}$ and was $0.9 \mathrm{bar}$ at the $120-\mathrm{cm}$ depth. Also, on this date at 1:00 PM

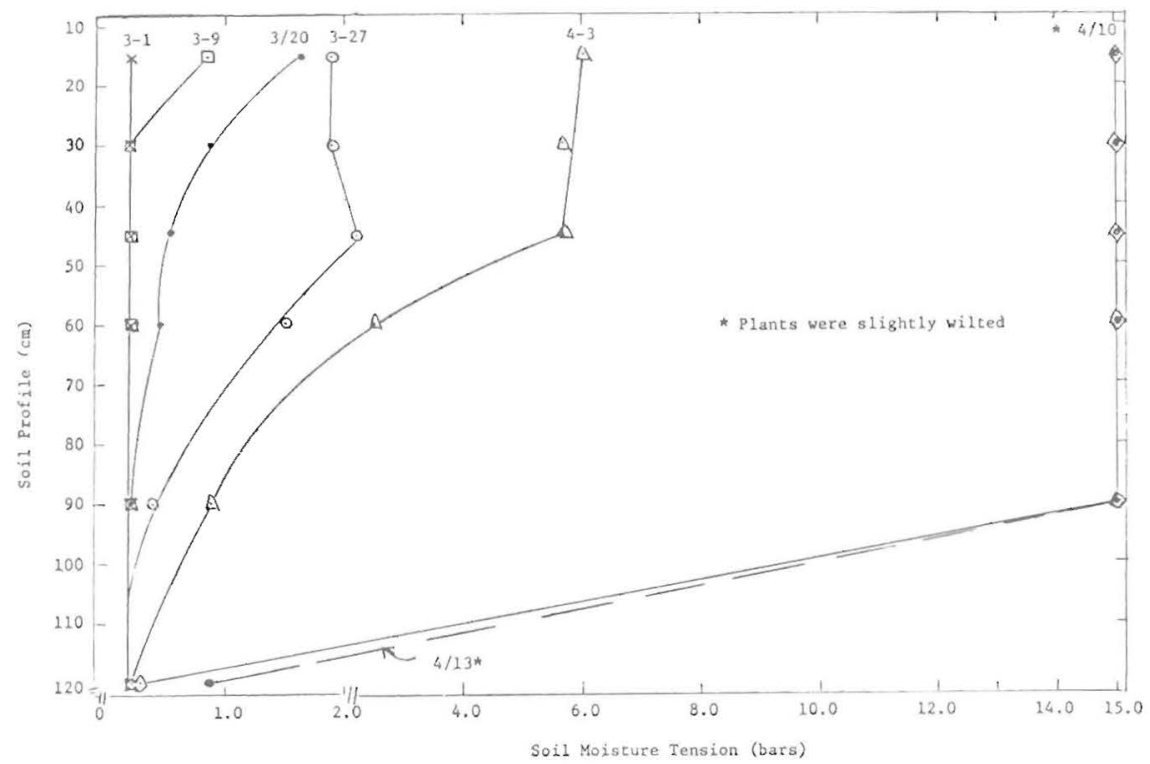

FIG. 2.-Water depletion in an Oxisol (Barranquitas) supporting corn growth during a drought period.

plants were observed to be slightly wilted. Water loss from the soil profile was so great that the upper $35 \mathrm{~cm}$ of test plots had cracks between 5 and $6.25 \mathrm{~cm}$ wide. During the period March 1 to April 13, rainfall amounted to $87 \mathrm{~mm}$ and evaporation accounted for $184.6 \mathrm{~mm}$ (table 2).

Figure 3 shows that at Corozal plants were severely wilted (some permanently) on May 11, just 18 dry days following a 406-mm rainfall. As can be seen, the soil moisture tension at the 15- and 30-cm depths were 11 and 15 bars, respectively, while the remaining soil profile was at field capacity. These results indicate that, in the Ultisol, corn plants were not able to effectively utilize soil water beyond a depth of $30 \mathrm{~cm}$. During the 
period of April 24 to May 11, evaporation accounted for $91.4 \mathrm{~mm}$ and $56.17 \mathrm{~mm}$ of rainfall were recorded.

Actual depths and distribution patterns of corn roots growing in the two soils are shown in the following tabulation:

$\begin{array}{rcc}\text { Soil } & \text { Maximum root depth. } \mathrm{cm} & \begin{array}{c}\text { Depth of } 75 \mathrm{r} \text { of } \\ \text { total roots, } \mathrm{cm}\end{array} \\ \text { Oxisol } & 90 \text { to } 95 & 50 \\ \text { Ultisol } & 25 \text { to } 30 & 12\end{array}$

In Barranquitas roots of both irrigated and nonirrigated plants were observed at depths of 90 to $95 \mathrm{~cm}$. However, observations at Corozal

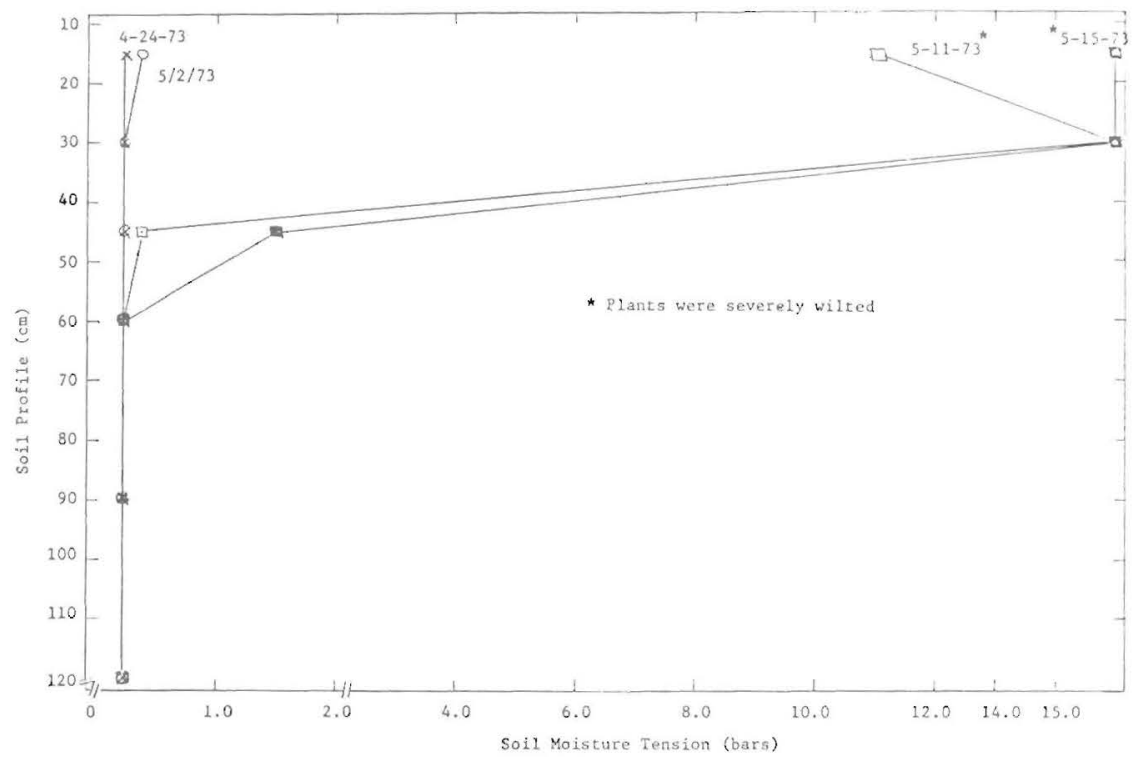

FIG. 3.-Water depletion in an Ultisol (Corozal) supporting corn growth during a drought period.

revealed that maximum rooting depths of both irrigated and nonirrigated plants were 25 to $30 \mathrm{~cm}$. Studies on root distribution patterns showed that in the Oxisol approximately $75 \%$ of the total roots were confined to the upper 50 -cm depth whereas in the Ultisol about $75 \%$ of the roots were found in the upper $12 \mathrm{~cm}$.

It is evident from these data that vertical soil water movement was extremely limiting in the test plots at Corozal, but not at Barranquitas. Apparently root growth was severely restricted. One plausible explanation for this difference is the higher bulk density, greater soil strength, and lower porosity of the soil at Corozal compared to that at Barran- 
quitas. Other workers have shown that corn root elongation almost ceased as soil strength was increased to 25 bars (7).

\section{WATER AVAILABILITY AND PLANT WATER DEFICITS}

Results of plant water deficits during a drought period at Barranquitas and Corozal are presented in table 3 . Water deficits were observed in plants growing under both irrigated and nonirrigated conditions. However, nonirrigated plants were under greater water stress than irrigated plants. Also, water deficit values of plants growing in the Ultisol were consistently greater than those of plants growing in the Oxisol. The

TABLE 3.- Mean leaf water deficits ( $L W D$ ) of corn plants growing with and without irrigation in an Oxisol (Barranquitas) and in an Ultisol (Corozal)

\begin{tabular}{|c|c|c|c|c|c|c|c|}
\hline \multicolumn{4}{|c|}{ Oxisol (Barranquitas) } & \multicolumn{4}{|c|}{ Ultisol (Corozal) } \\
\hline \multirow{2}{*}{$\begin{array}{l}\text { Sampling } \\
\text { date }\end{array}$} & \multirow{2}{*}{$\begin{array}{l}\text { Time of } \\
\text { day }\end{array}$} & \multicolumn{2}{|c|}{ LWD } & \multirow{2}{*}{$\begin{array}{c}\text { Sampling } \\
\text { date }\end{array}$} & \multirow{2}{*}{$\begin{array}{l}\text { Time of } \\
\text { day }\end{array}$} & \multicolumn{2}{|c|}{ LWD } \\
\hline & & Irrigated & $\begin{array}{l}\text { Nonirri- } \\
\text { gated }\end{array}$ & & & Irrigated & $\begin{array}{l}\text { Nonirri- } \\
\text { gated }\end{array}$ \\
\hline \multicolumn{6}{|c|}{$\%$} & \multicolumn{2}{|c|}{$\%$} \\
\hline $4-3-73$ & 2:00 PM & 8.92 & 13.10 & $4-6-73$ & 1:00 PM & 5.97 & 9.10 \\
\hline $4-5-73$ & $12: 00 \mathrm{~N}$ & 8.43 & 11.96 & $4-9-73$ & $8.00 \mathrm{AM}$ & 2.39 & 9.16 \\
\hline $4-6-73$ & 10:30 AM & 4.00 & 5.24 & & $10: 30 \mathrm{AM}$ & 10.70 & 18.35 \\
\hline \multirow{3}{*}{$4-10-73$} & 10:00 AM & 5.48 & 8.07 & $4-12-73$ & 1:00 PM & 4.49 & 4.04 \\
\hline & $12: 00 \mathrm{~N}$ & 3.33 & 10.99 & & 10:30 AM & 12.92 & 14.51 \\
\hline & 2:00 PM & 8.59 & 14.01 & $5-15-73$ & 1:30 PM & 10.02 & 19.80 \\
\hline \multirow[t]{2}{*}{$4-11-73$} & 10:00 AM & 2.66 & 10.17 & $5-17-73$ & 1:30 PM & 7.46 & 9.12 \\
\hline & 4:00 PM & 3.48 & 5.50 & $5-21-73$ & 1:00 PM & 4.73 & 13.50 \\
\hline $4-17-73$ & 2:00 PM & 3.88 & 6.10 & $5-23-73$ & 1:00 PM & 11.00 & 21.00 \\
\hline $4-18-73$ & 10:00 AM & 4.50 & 10.30 & $5-24-73$ & $11: 45 \mathrm{AM}$ & 10.46 & 14.63 \\
\hline Mean & & 5.33 & 9.54 & & & 8.01 & 13.32 \\
\hline
\end{tabular}

water tension values at the $45-\mathrm{cm}$ soil depth were 15.0 bars at Barranquitas and 0.2 at Corozal, indicating that although there was considerable moisture in the soil at Corozal, it was essentially unavailable for crop growth.

CROP YIELD

Yield data are presented in table 4. Pioneer X-306 corn yields at Barranquitas were higher than any previously reported values (4). Grain yields exceeded 8.1 tons/ha (130 bu/acre) in both irrigated and nonirrigated plots. The irrigated plots yielded 9.2 tons/ha (147 bu/acre), 13\% more than the nonirrigated plots. However, stover yields of nonirrigated plots were $16 \%$ greater than those of the irrigated plots. These differences in grain and stover yields could be attributed to moisture stress which 
was observed in nonirrigated plants at the time of grain filling and after plants had completed vegetative growth.

At Corozal corn yields of both irrigated and nonirrigated plots were lower than the average values obtained in soil fertility trials conducted over the past 3 years (4). It appears that time of planting and age of harvest are important factors. The Corozal crop was planted 28 days after the Barranquitas crop and harvested at only 129 days, while the Barranquitas crop was harvested at 159 days. There was essentially no difference in grain yields due to irrigation, the irrigated and nonirrigated plots producing 3.01 tons/ha (48 bu/acre) and 2.78 tons/ha ( $46 \mathrm{bu} / \mathrm{acre}$ ) of grain, respectively. These yields were about $33 \%$ of those obtained at Barranquitas. Stover yields of the irrigated plots were $83 \%$ greater than those of nonirrigated plots due to the severe moisture stress experienced by plants growing on the nonirrigated plots (fig. 3). At Corozal, plots were supplied with enough water to prevent permanent wilting.

TABLE 4.-Grain and stover yields of corn growing in an Oxisol and in an Vltisol with and without irrigation

\begin{tabular}{clcc}
\hline Soil & Treatment & $\begin{array}{c}\text { Grain yield } \\
(15 \% \text { water })\end{array}$ & $\begin{array}{c}\text { Stover yield } \\
(100 \% \text { dry matter })\end{array}$ \\
\hline \multirow{3}{*}{ Oxisol } & Irrigated & $K g / h a$ & $K g / h a$ \\
& Nonirrigated & 8274 & 5396 \\
& & 7374 & 6249 \\
\multirow{2}{*}{ Ultisol } & Irrigated & & 4976 \\
& Nonirrigated & 2696 & 2708 \\
\hline
\end{tabular}

During the experimental period $538.4 \mathrm{~mm}$ of rain fell at Barranquitas, and evaporation from a class A pan amounted to $692.1 \mathrm{~mm}$ (table 2). This deficit of $152.4 \mathrm{~mm}$ was more than offset by applying $177.8 \mathrm{~mm}$ of water to the irrigated plot. On the other hand, rainfall and evaporation at Corozal during the experimental period accounted for 818.4 and 613.9 $\mathrm{mm}$, respectively. However, over $393.7 \mathrm{~mm}$ of this precipitation fell over a continuous 6-day period that immediately preceeded tasseling (table 2). During this experimental period, $355.6 \mathrm{~mm}$ of water were applied to the irrigated plot and $228.6 \mathrm{~mm}$ were applied to the nonirrigated plots to prevent plants from permanently wilting. It appears that in the Ultisol at Corozal, crop growth and yields were limited by factors other than fertility and moisture. The high soil strength (25 to 28 bars) probably reduced oxygen diffusion rates. Also, roots seemed unable to elongate or proliferate as well as in the Oxisol at Barranquitas. It is evident that the corn plants were able to utilize the available moisture more efficiently in the Oxisol at Barranquitas than in the Ultisol at Corozal. 


\section{RESUMEN}

En este estudio se provee información de carácter fundamental para ayudar a clarificar las relaciones entre el crecimiento, los redimientos, la profundidad de penetración las raíces de maßz y la disponibilidad de agua en suelos Ultisols y Oxisols.

El maíz se sembró a principios de enero de 1973 en Barranquitas y Corozal. Las parcelas experimentales se encalaron, se abonaron y se trataron con pesticidas. En Corozal hubo que resembrar en febrero por la baja germinación de la semilla. Se tomaron datos meteorológicos, de la humedad del suelo y la tensión con que ésta se retenia, del crecimiento y los déficits hídricos de las plantas y de la profundidad de penetración de las raíces. Al cosechar, tanto el grano como el rastrojo se pesaron. En cada localidad, se regó una parcela cuantas veces fue necesario para mantener la tensión de agua del suelo a menos de I bar.

Los resultados indican que: 1) durante una sequía prolongada y en la etapa en que está llenándose el grano, el maíz sembrado en el Oxisol extrae agua hasta a $120 \mathrm{~cm}$. de profundidad; las plantas sufren por falta de agua después que la tensión, a una profundidad de $90 \mathrm{~cm}$., llega a 15 bares; 2) en el Ultisol, las plantas de maîz no pueden extraer agua del suelo eficazmente a profundidades mayores de $30 \mathrm{~cm}$; 3) el desarrollo de las plantas fue mayor en el Oxisol en Barranquitas que en el Ultisol en Corozal; 4) los rendimientos de maĩz en el Oxisol se aproximaron a las 9.4 $\mathrm{T} / \mathrm{Ha}$; y 5) la compactación relativa del Ultisol es mayor que la del Oxisol

\section{LITERATURE CITED}

1. Aldrich, S. R., and Leng, E. R., Modern corn production, F \& W Publishing Corp., U.S.A., p. 169, 1972.

2. Catsky, T., Leaf-disc method for determining water saturation deficit, UNESCO, Arid Zone Res. 25: 353-60. UNESCO, Paris, 1965.

3. Compaction of agricultural soils, Amer. Soc. Agr. Eng., Michigan, U.S.A., p. 249, 1971.

4. Fox, R. H., Talleyrand, H., and Bouldin, D. R., Nitrogen fertilization of corn and sorghum grown in Oxisols and Ultisols in Puerto Rico, Agron. J. 66: 534-40, 1974.

5. Grimes, D. W., Miller, R. J., Schweers, V. H., Smith, R. B., and Wiley, P. L., Soil strength modification of root development and soil water extraction, Calif. Agr. 26(11): 12-14, 1972.

6. Lund, Z. F., Soil compaction often limits cotton yields in Alabama, Highlights Agr. Res., 14(4), Agr. Exp. Sta., Auburn Univ., Auburn, Ala., 1967.

7. Mirreh, H. F., and Ketcheson, J. W., Influence of soil water matrix potential and resistance to penetration on corn root elongation, Can. J. Soil Sci. 53: 383-8, 1973.

8. Vomocil, TJ A., and Flocker, W. T., Soil compaction-its effects on storage and movement of soil, air and water, Trans. Amer. Soc. Agr. Eng. 4: 242-6, 1961. 